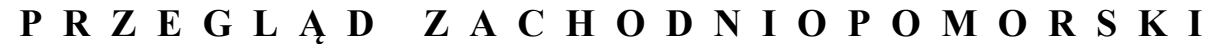 ROCZNIK XXXV (LXIV) ROK 2020 ZESZYT 3
}

\section{$\begin{array}{lllllllll}\mathbf{A} & \mathbf{R} & \mathbf{T} & \mathbf{Y} & \mathbf{K} & \mathbf{U} & \mathbf{L} & \mathbf{Y}\end{array}$}

\author{
SZCZEPAN STEMPIŃSKI \\ https://orcid.org/0000-0001-9544-7435 \\ Uniwersytet Szczeciński \\ e-mail: szczepan.stempinski@usz.edu.pl
}

\section{WPŁYW EPIDEMII WIRUSA SARS-COV-2 NA BEZPIECZEŃSTWO SzCZECIŃSKIEGo OBSZARU Metropolitalnego}

Słowa kluczowe: stan bezpieczeństwa, obszar metropolitalny, epidemia SARS-CoV-2 Keywords: security level, metropolitan area, SARS-CoV-2 epidemic

\section{Wprowadzenie}

Światowa epidemia, z którą zetknęli się mieszkańcy większości krajów na początku 2020 roku, stanowi wyzwanie, a zarazem doświadczenie, które należy identyfikować jako jedno z najpoważniejszych zagrożeń dla współczesnego bezpieczeństwa. Burzy to dotychczas powszechny prymat terroryzmu jako głównego zagrożenia dla globalnego bezpieczeństwa. Przemawia za tym choćby podjęcie nadzwyczajnych - zróżnicowanych co do skutku - przygotowań przez władze publiczne państw dotkniętych epidemią w skali niespotykanej dotychczas w świecie. Dotyczy to przede wszystkim obszaru Europy jako jednego z głównych ognisk epidemii. Autor w niniejszym artykule podjął próbę charakterystyki wybranych aspektów bezpieczeństwa mieszkańców Szczecińskiego Obszaru Metropolitalnego (dalej SOM) jako jedynego tak zdefiniowanego obszaru w Polsce, leżącego w pasie granicy państwowej, z dominującą rolą Gminy Miasta Szczecin 
jako jednego z kluczowych obszarów systemu osadniczego Polski1. W tym kontekście istotne jest również funkcjonowanie podsystemu ochrony zdrowia, do czego autor odniósł się w dalszej części opracowania.

Zdefiniowanie wszystkich aspektów charakteryzujących stan bezpieczeństwa $^{2}$ zdecydowanie wykracza poza ramy niniejszego artykułu. Autor, stosując metodę badania dokumentów, poddał analizie zarówno zmienne o charakterze jakościowym, jak i ilościowym³ ${ }^{3}$ Jednocześnie zaznacza, że z uwagi na diagnozowany obszar dokonał selekcji i redukcji tych danych, wykorzystując jedynie te, które pozwalają na wykonanie analizy porównawczej (analizowane okresy to 1.03-31.05. 2019 i 2020 roku). Wśród nich znajdują się wybrane akty normatywne oraz akty wewnętrznego kierowania (zalecenia i polecenia), a także szereg danych ilościowych uzyskanych od podmiotów odpowiedzialnych za bezpieczeństwo i porządek publiczny oraz ochronę przeciwpożarową. Stan epidemii stanowi nowe istotne zagrożenie, które może wywierać wpływ na stan bezpieczeństwa mieszkańców SOM-u. Rozwiązania tak sformułowanego problemu badawczego autor poszukiwał poprzez uzyskanie odpowiedzi na następujące pytania ${ }^{4}$ :

1. Czy stan epidemii w pierwszych trzech miesiącach jej trwania wpłynął na obniżenie poziomu bezpieczeństwa mieszkańców Szczecińskiego Obszaru Metropolitalnego?

2. Czy jednym z czynników wpływających na stan bezpieczeństwa może być zmniejszona aktywność mieszkańców w przestrzeni publicznej?

Jednocześnie autor sformułował hipotezę, że stan bezpieczeństwa mieszkańców SOM-u w analizowanym okresie epidemii wirusem SARS-CoV-2 nie uległ pogorszeniu. W tym celu autor porównał dane statystyczne pochodzące od właściwych terytorialnie jednostek: Policji, Państwowej Straży Pożarnej, Urzędu Stanu Cywilnego, Państwowej Inspekcji Sanitarnej oraz podmiotów komunalnych.

1 Koncepcja Przestrzennego Zagospodarowania Kraju 2030, dostęp 25.06.2020, http:// www.wzs.wzp.pl/sites/default/files/files/19683/89272000_1412985316_Koncepcja_Przestrzennego_Zagospodarowania_Kraju_2030.pdf, 22, 37-74.

2 Ryszard Jakubczak, red., Obrona narodowa w tworzeniu bezpieczeństwa III RP (Warszawa: Bellona, 2003), 15-16.

3 Jerzy Apanowicz, Metodologia ogólna (Gdynia: Bernardinum, 2002), 54, 68, 69.

4 Andrzej Jan Chodubski, Wstęp do badań politologicznych (Gdańsk: Wydawnictwo Uniwersytetu Gdańskiego, 2011), 173-175. 


\section{Charakterystyka Szczecińskiego Obszaru Metropolitalnego}

Szczeciński Obszar Metropolitalny zaczął funkcjonować 15 kwietnia 2005 roku. Wtedy to powołano Samorządowe Stowarzyszenie Współpracy Regionalnej, które we wrześniu 2009 roku zmieniło nazwę na Stowarzyszenie Szczecińskiego Obszaru Metropolitalnego. W jego skład (na dzień 31.05.2020 r.) wchodzi 15 jednostek samorządu terytorialnego: województwo zachodniopomorskie, powiat policki, miasta: Stargard, Świnoujście i Szczecin oraz gminy: Dobra Szczecińska, Goleniów, Gryfino, Kobylanka, Kołbaskowo, Nowe Warpno, Stare Czarnowo, Police, Stargard i Stepnica. Obszar ten obejmuje blisko $2800 \mathrm{~km}^{2}$ i jest zamieszkały przez 690 tys. osób. Choć składa się z odrębnych jednostek administracyjnych, stanowi jednak układ o ciągłości osadniczo-przestrzennej. Zarówno jego potencjał ludnościowy (40\% ludności województwa), przestrzenny (11,35\% powierzchni województwa), jak i gospodarczy (45,8\% ogółu podmiotów gospodarczych) określają skalę jego powiązań funkcjonalnych oraz kluczowe znaczenie w zachodniej części Rzeczpospolitej5. Warto przy tym zauważyć, że Szczecin jako kluczowy element obszaru należy do grupy nielicznych miast $\mathrm{w}$ Polsce, w których znajdują się instytucje międzynarodowego bezpieczeństwa - jest siedzibą Wielonarodowego Korpusu Północno-Wschodniego NATO.

Obszary funkcjonowania metropolii stanowią model współdziałania gmin i powiatów ukierunkowany na realizację zadań publicznych dla mieszkańców tych obszarów. Zgodnie z Koncepcją Przestrzennego Zagospodarowania Kraju (KPZK) Szczecin należy do głównych składników systemu osadniczego, o podstawowym znaczeniu dla kraju i jego gospodarki (wraz z takimi miastami i zespołami miast, jak: Warszawa, Kraków, Gdańsk-Gdynia, Wrocław, Poznań, Katowice-Aglomeracja Górnośląska, Łódź, Bydgoszcz z Toruniem i Lublin). Wyznaczniki charakteryzujące ośrodki metropolitalne to m.in.:

- liczba ludności (powyżej 300 tys. mieszkańców),

- zatrudnienie w sektorze usług rynkowych (powyżej 40 tys.),

- liczba studentów kształcących się (powyżej 60 tys.),

- współpraca instytucji naukowo-badawczych (5 i 6 Program ramowy UE),

- lokalizacja portu lotniczego obsługującego ruch pasażerski,

- lokalizacja hoteli cztero- i pięciogwiazdkowych,

5 Dane o województwie - kwiecień 2020, dostęp 31.05.2020, https://szczecin.stat.gov.pl/wojewodztwo/. 
- organizacja międzynarodowych wystaw w obiektach działalności wystawienniczej w latach 2006-20086).

Szczecin jako główne miasto obszaru został wskazany w opracowaniach przygotowywanych dla celów polityki przestrzennej w skali Unii Europejskiej jako tzw. MEGA, wśród 72 największych ośrodków miejskich UE 55, choć trzeba dostrzec $\mathrm{w}$ jego przypadku niepełny profil funkcjonalny przy ograniczonym potencjale ludnościowym i rynkowym. Szczecin należy w konsekwencji do podkategorii MEGA 3 (słabo wykształcone metropolie - w Polsce są to także: Gdańsk, Poznań, Wrocław, Łódź, Katowice i Kraków), a także jest członkiem Unii Metropolii Polskich zrzeszającej 12 głównych miast kraju. Należy zaznaczyć, że Krajowa Strategia Rozwoju Regionalnego z 2010 roku dostrzegała negatywne trendy gospodarcze w odniesieniu do Szczecina (na przestrzeni 7 lat zmiana PKB per capita nie przekroczyła 30\%, przy średniej krajowej wynoszącej prawie 59\%), co stanowi wyzwanie szczególnie w warunkach poprawy jakości infrastruktury komunikacyjnej, zwiększenia mobilności przestrzennej i zawodowej. Wskazuje także na skalę powiązań funkcjonalnych (społecznych, gospodarczych, przestrzennych, komunikacyjnych) w ramach obszaru. Warto przy tym nadmienić, że branża transportu morskiego - która stanowi znaczący wolumen gospodarki SOM-u (znajduje się tam Zespół Portów Szczecin-Świnoujście) - dotknięta została znaczącym spadkiem obrotów. Dotyczyło to zarówno „ładunków masowych, jak i skontenerowanych”7, bowiem „Polska Zachodnia [...], której głównym ośrodkiem jest Szczecin, staje się obszarem zintegrowanym funkcjonalnie z głównymi obszarami aktywności gospodarczej w centrum kraju oraz wzdłuż wybrzeża Bałtyku. Wykształceniu ulegają powiązania o charakterze międzynarodowym - przede wszystkim z Berlinem (na czym w szczególności może skorzystać Szczecin) i Saksonią, a także miastami i regionami położonymi po obu stronach Bałtyku (Kopenhagą, Skanią i Sztokholmem). Sprzyja to wykorzystaniu szans związanych z intensyfikacją integracji politycznej i społeczno-gospodarczej Polski i metropolii sieciowej z podstawowym obszarem koncentracji aktywności gospodarczej w UE (do której należy większość obszaru zarówno Niemiec, jak i Czech). Obszar styku i największych wzmocnień oddziaływań

\footnotetext{
6 Koncepcja, 167.

7 Współczesne kryzysy gospodarcze z perspektywy branży morskiej, dostęp 4.07.2020, https:// www.gov.pl/web/gospodarkamorska/wspolczesne-kryzysy-gospodarcze-z-perspektywy-branzy-morskiej.
} 
leży m.in. wzdłuż zachodniej granicy Polski”». Konkludując - Szczecin oraz SOM znajdują się w strefie oddziaływania środkowoeuropejskiego i bałtyckiego obszaru integracji w Europie.

\section{Aspekt funkcjonalno-normatywny}

Zwalczanie zagrożenia epidemicznego znajduje swoje odzwierciedlenie w planach zarządzania kryzysowego tworzonych na poziomie jednostek samorządu terytorialnego (dalej: jst), krajowym i resortowym. Należy przy tym podkreślić, że plany te tworzone są według jednolitej metodologii na każdym z poziomów i zawierają odpowiednio: plan powiatowy - plany gminne, plan wojewódzki - plany powiatowe, plan krajowy - plany wojewódzkie i resortowe. Ten wieloszczeblowy układ systemowy zarządzania kryzysowego odzwierciedlają również rozwiązania normatywne ${ }^{9}$, zaś ich wspólnym głównym celem jest permanentna identyfikacja zagrożeń, przygotowanie sił i środków niezbędnych do ich zwalczania i odbudowy środowiska dotkniętego zagrożeniem.

Autor charakteryzował podejście funkcjonalno-normatywne w zakresie zwalczania koronawirusa SARS-CoV-2 na przykładzie Miejskiego Planu Zarządzania Kryzysowego (dalej MPZK) ${ }^{10}$ opracowanego dla Gminy Miasto Szczecin, który jest zarówno planem gminnym, jak i powiatowym (Prezydent Miasta Szczecin jest również starostą grodzkim). Jednocześnie autor przyjął założenie, że z uwagi na wieloaspektowy, dominujący charakter Szczecina w układzie SOM-u, takie podejście będzie reprezentatywne dla diagnozy zjawiska. Opisywany dokument został zaktualizowany w grudniu ubiegłego roku i zaakceptowany przez Wojewodę Zachodniopomorskiego (dalej WZ) w kwietniu roku bieżącego. Jest więc dokumentem aktualnym oraz reprezentatywnym dla wszystkich jst tworzących SOM. Z uwagi na jego obszerność (blisko 600 stron) autor jedynie zasygnalizuje jego istotę.

Jedną z kluczowych części każdego planu zarządzania kryzysowego jest siatka bezpieczeństwa. To tabelaryczne zestawienie zidentyfikowanych zagrożeń i przypisanych do nich podmiotów (wiodących i współpracujących) porządkuje ich kompetencje władcze w każdej z czterech faz zarządzania kryzysowego

\footnotetext{
8 Koncepcja, 42-43.

9 Ustawa z 26.04.2007 o zarządzaniu kryzysowym, Dz.U. 2007, nr 89, poz. 590, z późn. zm., art. 4 i 5.

10 Miejski Plan, dostęp 14.06.2020, http://bip.um.szczecin.pl/files/5F5F2355610B4CF0935EDF038D14EBB0/Miejski_Plan_Zara\%C4\%85dzania_Kryzysowego.pdf.
} 
(zapobiegania, przygotowania, reagowania i odbudowy), ale również sprzyja rozstrzyganiu ewentualnych sporów kompetencyjnych. Sam plan składa się z trzech zasadniczych części.

W części pierwszej - planie głównym - zidentyfikowano epidemię jako drugie z potencjalnych zagrożeń naturalnych przyjmując, że:

- planowany zasięg jej oddziaływania może być wynikiem przemieszczania się ludności transportem drogowym, kolejowym, lotniczym i morskim,

- istnieje średnie ryzyko jej wystąpienia,

- możliwy jest gwałtowny wzrost zachorowań ludzi na choroby zakaźne wywoływane przez 43 patogeny, powodujące zagrożenie epidemiczne, wśród nich m.in. SARS,

- możliwe będą skuteczne działania o charakterze reaktywnym niwelujące skutki zagrożenia (dla ludności, gospodarki/infrastruktury i środowiska).

W drugiej części MPZK znajdują się dwie procedury reagowania kryzysowego (PRK 13 i PRK 14) dedykowane epidemii (łącznie jest ich 39). Pierwsza $\mathrm{z}$ nich przewiduje zaplanowane działania $\mathrm{w}$ sytuacji wystąpienia zagrożenia epidemicznego, których celem jest minimalizacja zagrożeń związanych z możliwością wybuchu epidemii oraz stworzenie dogodnych warunków do ogłoszenia tego stanu. Koordynację działań w tym zakresie powierza się Prezydentowi Miasta Szczecin. Druga procedura uruchamiana jest już w obliczu stanu epidemii, który może być ogłoszony przez WZ lub ministra właściwego do spraw zdrowia. Rolę koordynatora pełni w niej wojewoda. W każdą z wymienionych procedur zaangażowanych jest wiele podmiotów zajmujących się sprawami społecznymi i komunalnymi, ochroną zdrowia czy bezpieczeństwem publicznym. Należy podkreślić, że w opracowanych procedurach istotne znaczenie przypisuje się mediom i komunikacji z mieszkańcami.

Część trzecia MPZK zawiera dwanaście załączników funkcjonalnych, wśród których znajdują się dwa wprost odnoszące do stanu epidemii:

1. Działania Powiatowej Stacji Sanitarno-Epidemiologicznej w Szczecinie w sytuacjach kryzysowych (PRZ 3). Tu rolę wiodącą pełni Powiatowy Inspektor Sanitarno-Epidemiologiczny w Szczecinie, którego postępowanie zostało usystematyzowane szczegółowo w trzech fazach (zapobiegawczej, rozwinięcia i zakończenia działań przeciwepidemicznych).

2. Organizacja pomocy medycznej, opieki socjalnej i pomocy społecznej. Jest to szczegółowa charakterystyka potencjału, jakim dysponuje GMS wraz z precyzyjnym opisem zadań, form działania, modeli zarządzania czy w końcu 
szczegółowych wykazów wraz z aktualnymi danymi adresowymi i kontaktowymi podmiotów zaangażowanych w system zarządzania kryzysowego.

Autor zakłada, że zaplanowane powyżej rozwiązania w zakresie planistycznym i proceduralnym są tożsame dla wszystkich jst wchodzących w skład SOM-u. Dotyczy to zarówno założonych celów, rozwiązań normatywnych oraz funkcjonalnych. Różnice pomiędzy jst wynikają jedynie z ich potencjału (możliwości skutecznego przeciwdziałania zagrożeniom bez zewnętrznego wsparcia).

Wymiar normatywny dotyczący możliwości skutecznego zwalczania zagrożeń epidemicznych zostanie przez autora scharakteryzowany sygnalnie. Wynika to $\mathrm{z}$ dwóch powodów: dynamiki zmian $\mathrm{w}$ prawie (szczególnie $\mathrm{w}$ okresie 1.03-31.05.2020 r.) oraz podmiotowo-przedmiotowej ich rozległości. W ocenie autora ich szczegółowa, retrospektywna charakterystyka winna być dokonana z perspektywy holistycznej, po wygaszeniu epidemii.

Zagrożenie epidemią zidentyfikowane w MPZK (zarówno w warstwie analitycznej, jak i proceduralnej) opierało się głównie na obowiązującym na dzień 31 grudnia 2019 roku ustawowym rozwiązaniu normatywnym ${ }^{11}$, które szczegółowo określało;

„1) zasady i tryb zapobiegania oraz zwalczania zakażeń i chorób zakaźnych u ludzi, w tym zasady i tryb rozpoznawania i monitorowania sytuacji epidemiologicznej oraz podejmowania działań przeciwepidemicznych i zapobiegawczych w celu unieszkodliwienia źródeł zakażenia, przecięcia dróg szerzenia się zakażeń i chorób zakaźnych oraz uodpornienia osób podatnych na zakażenie;

2) zadania organów administracji publicznej w zakresie zapobiegania oraz zwalczania zakażeń i chorób zakaźnych u ludzi;

3) uprawnienia i obowiązki świadczeniodawców oraz osób przebywających na terytorium Rzeczypospolitej Polskiej w zakresie zapobiegania oraz zwalczania zakażeń i chorób zakaźnych u ludzi”.

Ustawa zawiera również 39 szczegółowo zdefiniowanych określeń dotyczących różnych stanów, w tym epidemię jako ,wystąpienie na danym obszarze zakażeń lub zachorowań na chorobę zakaźną w liczbie wyraźnie większej niż we wcześniejszym okresie albo wystąpienie zakażeń lub chorób zakaźnych dotychczas niewystępujących".

Jednak przewidziane rozwiązania normatywne okazały się niewystarczające do skutecznej walki z koronawirusem SARS-CoV-2, którego epidemia

11 Ustawa z 5.12.2008 o zapobieganiu oraz zwalczaniu zakażeń i chorób zakaźnych u ludzi, Dz.U. 2008, nr 243, poz. 1570, z późn. zm. 
dotknęła Europę, w tym również Polskę. Konieczne było bezzwłoczne wprowadzenie do obrotu prawnego przepisów lex specialis, które w zamyśle autorów umożliwić miały skuteczne przeciwdziałanie epidemii. Z uzasadnienia do ich pilnego wprowadzenia, które przedstawił Sekretarz Stanu w KPRM podczas posiedzenia Komisji Zdrowia Sejmu RP 2 marca 2020 roku wynika, że

celem [...] jest oczywiście zminimalizowanie zagrożeń powstałych lub mogących powstać wskutek epidemii wirusa [...] a [...] podstawowe zapisy tego projektu, to, po pierwsze, przewidzenie możliwości zlecania pracy zdalnej w czasie kwarantanny lub nadzoru epidemiologicznego; przyznanie opiekunom dzieci zasiłków na czas zamknięcia żłobka, przedszkola lub szkoły; zwolnienie z kontroli na lotniskach służb medycznych; możliwość wyłączenia prawa zamówień publicznych w odniesieniu do zamówień niezbędnych do przeciwdziałania tej chorobie; możliwość nałożenia przez Prezesa Rady Ministrów, na wniosek Ministerstwa Zdrowia, obowiązków na spółki lecznicze i samorządy, również w zakresie przeciwdziałania tej chorobie; możliwość wydawania przez wojewodę poleceń organom administracji w zakresie zwalczania tej choroby; możliwość wydawania przez prezesa Rady Ministrów poleceń innym podmiotom w zakresie zwalczania tej choroby; możliwość wyłączania prawa budowlanego oraz ustawy o ochronie zabytków oraz opiece nad zabytkami w zakresie przedsięwzięć związanych ze zwalczaniem tej choroby; możliwość wykonywania dodatkowych zadań przez żołnierzy w czynnej służbie wojskowej w zakresie zwalczania tej choroby; uprawnienie głównego inspektora sanitarnego do wydawania decyzji, zaleceń i czynności zapobiegawczych lub kontrolnych różnym osobom prawnym w zakresie zwalczania tej choroby; określenie zasad dystrybucji i dostępności produktów leczniczych; możliwość uproszczonego przekazywania dotacji finansowych dla jednostek samorządu terytorialnego; możliwość zatrudniania przez wojewodę dodatkowych ratowników medycznych; ułatwienie w nakładaniu obowiązków na chorych - ta sytuacja dotyczy przede wszystkim kwarantanny; uproszczenie przekazywania asortymentu przez Agencję Rezerw Materiałowych; możliwość przesuwania środków finansowych między działami budżetu oraz możliwość zawieszania działalności szkół oraz uczelni wyższych $^{12}$.

Należy również nadmienić, że przyjęcie tej ustawy spowodowało wiele zmian (w większości o charakterze prewencyjnym) w kolejnych 15 przepisach, wyposażając różne podmioty w dodatkowe zadania i uprawnienia. Autor przedstawił poniżej te, które w jego ocenie mają/miały istotny, bezpośredni wpływ

12 Zapis przebiegu, dostęp 16.06.2020, http://www.sejm.gov.pl/Sejm9.nsf/biuletyn.xsp?skrnr= ZDR-13. 
na stan bezpieczeństwa na terenie SOM-u. Znowelizowano bowiem kluczowe dla profilaktyki zwalczania epidemii zapisy ustalające:

- miejsce kwarantanny jako „odrębny obiekt budowlany czasowego pobytu osób chorych lub podejrzanych o zachorowanie, w którym prowadzi się kwarantannę"13,

- szczególne obowiązki wobec zakażonych, chorych, podejrzanych, polegające na „konieczności poddania izolacji lub kwarantannie osób [...], którym wojewoda zapewnia warunki izolacji lub kwarantanny przez zapewnienie odpowiednich pomieszczeń, wyposażenia oraz skierowanie do pracy osób posiadających odpowiednie kwalifikacje"14,

- obowiązkową hospitalizację, izolację (także w warunkach domowych, kwarantannę lub nadzór epidemiologiczny dla osób, „które pozostawały w styczności z osobami chorymi na choroby zakaźne [i które - dop. S.S.] podlegają obowiązkowej kwarantannie lub nadzorowi epidemiologicznemu, jeżeli tak postanowią organy inspekcji sanitarnej przez okres nie dłuższy niż 21 dni, licząc od ostatniego dnia styczności"15.

Szczególną dolegliwość dla ludności stanowiły przepisy zawieszające działalność żłobków, przedszkoli, szkół podstawowych i ponadpodstawowych oraz uczelni wyższych. Poza koniecznością dostosowania się do wymuszonych epidemią nowych form przekazywania i sprawdzania wiedzy pojawiła się konieczność zapewnienia opieki nad dziećmi.

Dla zapewnienia bezpieczeństwa na obszarze RP niezbędne było ogłoszenie przez Ministra Zdrowia (dalej MZ) - wiodącego podmiotu systemu zarzadzania kryzysowego w zakresie zwalczanie epidemii - szeregu ograniczeń, nakazów i zakazów obowiązujących podczas:

- stanu zagrożenia epidemicznego ogłoszonego w dniu 13.03.2020 r. ${ }^{16}$,

- stanu epidemii, ogłoszonego w dniu 20.03.2020 r. ${ }^{17}$.

13 Ustawa z 2.03.2020 o szczególnych rozwiązaniach związanych z zapobieganiem, przeciwdziałaniem i zwalczaniem COVID-19, innych chorób zakaźnych oraz wywołanych nimi sytuacji kryzysowych, Dz.U. 2020, poz. 374, art. 25 ust. 1.

14 Ustawa z 5.12.2008 o zapobieganiu oraz zwalczaniu zakażeń i chorób zakaźnych u ludzi, Dz.U. 2008, nr 243, poz. 1570, z późn. zm., art. 33 ust. 7.

15 Ustawa z 2.03.2020, art. 25 ust. 2.

16 Rozporządzenie Ministra Zdrowia z 13.03.2020 w sprawie ogłoszenia na obszarze Rzeczypospolitej Polskiej stanu zagrożenia epidemicznego, Dz.U. 2020, poz. 433.

17 Rozporządzenie Ministra Zdrowia z 20.03.2020 w sprawie ogłoszenia na obszarze Rzeczypospolitej Polskiej stanu epidemii, Dz.U. 2020, poz. 491. 
Powyższe akty wykonawcze miały również zasadnicze znaczenie dla funkcjonowania SOM-u, wprowadzały bowiem znaczące utrudnienia w kolejowym ruchu granicznym, polegające na konieczności wskazania funkcjonariuszowi Straży Granicznej przez osoby przekraczające granicę RP adresu miejsca zamieszkania lub pobytu, w którym będą one odbywać kwarantannę. Wyjątek od tego obowiązku ustalono dla osób, które wykonują czynności zawodowe w państwie sąsiadującym (także w Danii i Szwecji), w tym kierowców obsługujących pojazdy samochodowe $\mathrm{w}$ transporcie drogowym. Spowodowało to znaczący spadek liczby osób przekraczających granicę, a dodatkowo silne niezadowolenie mieszkańców terenów przygranicznych wywołane spadkiem obrotu gospodarczego $^{18}$. Do skutków wprowadzenia ograniczenia swobód, praw i wolności obywatelskich autor odniósł się w podsumowaniu niniejszego artykułu.

Za co najmniej zastanawiające autor postrzega wydanie z ponad dziesięciodniową zwłoką przez Radę Ministrów przepisów ustalających ograniczenia, nakazy i zakazy na obszarze RP objętym epidemią; są to:

1. „Ograniczenia określonego sposobu przemieszczania się oraz obowiązek poddania się kwarantannie.

2. Ograniczenia lub zakaz obrotu i używania określonych przedmiotów.

3. Ograniczenia funkcjonowania określonych instytucji lub zakładów pracy, czasowe ograniczenie określonych zakresów działalności przedsiębiorców oraz obowiązek wykonania określonych zabiegów sanitarnych.

4. Zakaz organizowania widowisk i innych zgromadzeń ludności.

5. Nakaz udostępnienia nieruchomości, lokali i terenów przewidzianych planami przeciwepidemicznymi.

6. Czasowe ograniczenie korzystania z lokali lub terenów oraz obowiązek ich zabezpieczenia.

7. Nakaz określonego sposobu przemieszczania się"19.

Dynamika rozwoju epidemii spowodowała, że rozporządzenie to było dwukrotnie nowelizowane - 10 kwietnia i 29 maja 2020 roku. Konsekwencją przyjętych przepisów były rozwiązania czasowo uniemożliwiające lub ograniczające działalność bibliotek, archiwów, muzeów oraz pozostałej aktywności związanej

18 Prezydent Szczecina i mieszkańcy apelują. Otwórzcie przejście graniczne w Lubieszynie!, Twojeradio.fm, dostęp 21.06.2020, https://twojeradio.fm/prezydent-szczecina-i-mieszkancy-apeluja-otworzcie-przejscie-graniczne-w-lubieszynie.html.

19 Rozporządzenie Rady Ministrów z 31.03.2020 w sprawie ustanowienia określonych ograniczeń, nakazów i zakazów w związku z wystąpieniem stanu epidemii, Dz.U. 2020, poz. 566, z późn. zm. 
z kulturą, realizację zadań przez urzędy administracji publicznej lub jednostki organizacyjne wykonujące zadania o charakterze publicznym - do niezbędnych w zakresie pomocy obywatelom oraz dla osób przebywających w środkach publicznego transportu zbiorowego. Nadto wprowadzono w nim obowiązek zakrywania, przy pomocy odzieży lub jej części, maski albo maseczki, ust i nosa przez osoby poruszające się środkami publicznego transportu zbiorowego w miejscach ogólnodostępnych. Dotyczyło to również dróg i placów, zakładów pracy czy budynków użyteczności publicznej.

Konsekwencją dyspozycji ustawowej było wydanie przez Ministra Edukacji Narodowej kolejnego rozporządzenia ograniczającego funkcjonowanie jednostek systemu oświaty w związku ze zwalczaniem epidemii COVID $19^{20}$.

Wskazane wyżej wybrane rozwiązania normatywne - co autor zdecydowanie podkreśla - wynikały z nadzwyczaj szybko postępującego rozwoju jednostki chorobowej, jaką jest COVID-19, na całym świecie. Jej rozwój - także na obszarach, które ogłosiły „przedwczesne zwycięstwo” - jest niezwykle intrygującym, interdyscyplinarnym wątkiem badawczym. Należy przy tym podkreślić, że medyczny aspekt poznawczy, który umożliwić może w przyszłości skuteczną walkę z koronawirusem SARS-CoV-2, stanowi wyzwanie praktycznie dla wszystkich ośrodków naukowo-badawczych na świecie. Rozwiązania normatywne mogą stanowić jedynie jeden $z$ istotnych determinantów, przy założeniu ich skutecznej egzekucji.

\section{Stan bezpieczeństwa Szczecińskiego Obszaru Metropolitalnego}

Analiza stanu bezpieczeństwa mieszkańców SOM-u, której autor dokonał w niniejszym artykule, opiera się na danych uzyskanych w ramach dostępu do informacji publicznej od podmiotów zaangażowanych w działania niwelujące skutki epidemii koronawirusa. Autor, z uwagi m.in. na ograniczenia edytorskie, dokonał selekcji szerokiego spektrum determinantów, co w jego przekonaniu pozwala na stosunkowo szerokie i zobiektywizowane spojrzenie diagnostyczne, a także na udzielenie odpowiedzi na sformułowane pytania. W katalogu analizowanych danych znalazły się dane liczbowe:

20 Rozporządzenie Ministra Edukacji Narodowej z 11.03.2020 w sprawie czasowego ograniczenia funkcjonowania jednostek sytemu oświaty $\mathrm{w}$ związku z zapobieganiem, przeciwdziałaniem i zwalczaniem COVID-19, Dz.U. 2020, poz. 410. 
- pojazdów wjeżdżających/wyjeżdżających na i z terenu Miasta Szczecin (dane uzyskane z Zakładu Dróg i Transportu Miejskiego w Szczecinie pochodzące z wag elektronicznych rozmieszczonych na drogach wjazdowych/wyjazdowych - jedynie te dane odnoszą się wyłącznie do Szczecina. Pozostałe charakteryzują już obszar całego SOM-u),

- zdarzeń w ruchu drogowym (w rozbiciu na kolizje i wypadki drogowe wraz z liczbą osób rannych i zabitych - dane uzyskane z KWP w Szczecinie),

- interwencji przeprowadzonych przez policjantów (w rozbiciu na interwencje policjantów ruchu drogowego oraz pozostałe - dane jw.),

- wszczętych postępowań przygotowawczych (wybrane, podstawowe kategorie przestępstw - bójka i pobicie, rozbój, kradzież z włamaniem, kradzież cudzej rzeczy, zabór i kradzież pojazdu, przestępstwa z ustawy o przeciwdziałaniu narkomanii w tym: posiadanie i udzielanie środków odurzających i substancji psychotropowych - dane jw.),

- pożarów, zdarzeń miejscowych oraz fałszywych alarmów (dane uzyskane z Komendy Miejskiej Państwowej Straży Pożarnej w Szczecinie),

- zachorowań, zgonów i testów (dotyczących epidemii koronawirusa - dane uzyskane z Wojewódzkiej Stacji Sanitarno-Epidemiologicznej w Szczecinie),

- zgonów (zarejestrowanych na terenie SOM-u - dane uzyskane z Urzędu Stanu Cywilnego w Szczecinie).

Autor jeszcze raz podkreśla publiczny charakter tych informacji oraz fakt, że charakteryzują one okres trzech początkowych miesięcy rozwoju epidemii w Polsce w stosunku do analogicznego okresu roku poprzedniego. Dane przedstawione zostały w formie tabel i rysunków. Należy przy tym zaznaczyć, że autor dokonał istotnej redukcji zakresu analizowanych danych (prezentuje je łącznie dla gmin tworzących SOM - jako właściwe miasto lub powiat), co ułatwia dokonanie porównań i stanowi wystarczająco szeroki materiał umożliwiający udzielenie odpowiedzi na postawione pytania. 
Tabela 1. Liczba pojazdów wjeżdżających i wyjeżdżających na teren Gminy Miasto Szczecin w badanym okresie

\begin{tabular}{|l|c|c|c|}
\hline \multirow{2}{*}{ Rok } & \multicolumn{3}{|c|}{ Liczba pojazdów wjeżdżających i wyjeżdżających na i z terenu Gminy Miasto } \\
\cline { 2 - 4 } & $1-31$ marca & $1-30$ kwietnia & $1-31$ maja \\
\hline 2019 & 2728091 & 2729968 & 2727461 \\
\hline 2020 & 2231698 & 2360925 & 1579368 \\
\hline
\end{tabular}

Źródło: opracowanie własne na podstawie danych uzyskanych z Zakładu Dróg i Transportu Miejskiego w Szczecinie.

W tabeli 1 przedstawiono dane dotyczące ruchu pojazdów. Należy podkreślić, że na terenie Szczecina funkcjonuje pięć punktów pomiarowych (wagi elektroniczne), które rejestrują zarówno całkowite liczby pojazdów - w roku 2019 zarejestrowały ich blisko $33 \mathrm{mln}$ - oraz liczby pojazdów o przekroczonym dopuszczalnym nacisku na oś. Prezentowane w tabeli dane wskazują jednoznacznie na znaczący spadek liczby pojazdów przemieszczających się na drogach wjazdowych/wyjazdowych ze Szczecina w analizowanym okresie epidemii. Średnia dzienna wartość rejestrowanych pojazdów przed epidemią wynosiła ponad 87 tys., zaś w maju 2020 roku osiągnęła zaledwie wartość 51 tys. pojazdów. Podobną tendencję z uwagi na wprowadzone ograniczenia w poruszaniu się autor przyjmuje dla całego obszaru SOM. Bez wątpienia jest to efekt opisywanych już zakazów, nakazów oraz ograniczeń w funkcjonowaniu i przemieszczaniu się osób.

Zmniejszone natężenie ruchu pojazdów miało bezpośredni wpływ na stan bezpieczeństwa w ruchu drogowym. Przemawia za tym liczba zdarzeń zarejestrowanych na terenie SOM-u. Odnotowano spadki we wszystkich kluczowych determinantach:

- spadek liczby kolizji o 35\% (wystąpił on we wszystkich analizowanych jednostkach wchodzących w jego skład),

- spadek liczby wypadków drogowych o 51\% (jedynie na terenie Świnoujścia i Gryfina liczba tych zdarzeń wzrosła, jednak nie miało to wpływu na ogólną tendencję),

- spadek liczby osób rannych o 57\% (podobnie jak w przypadku wypadków, jedynie na terenie Świnoujścia i Gryfina liczba tych zdarzeń wzrosła, co jest efektem tych zdarzeń; nie wpłynęło to jednak na ogólną tendencję spadkową)

- spadek liczby osób zabitych o 23\% (tu również odnotowano wzrost na terenie Świnoujścia i Gryfina). 


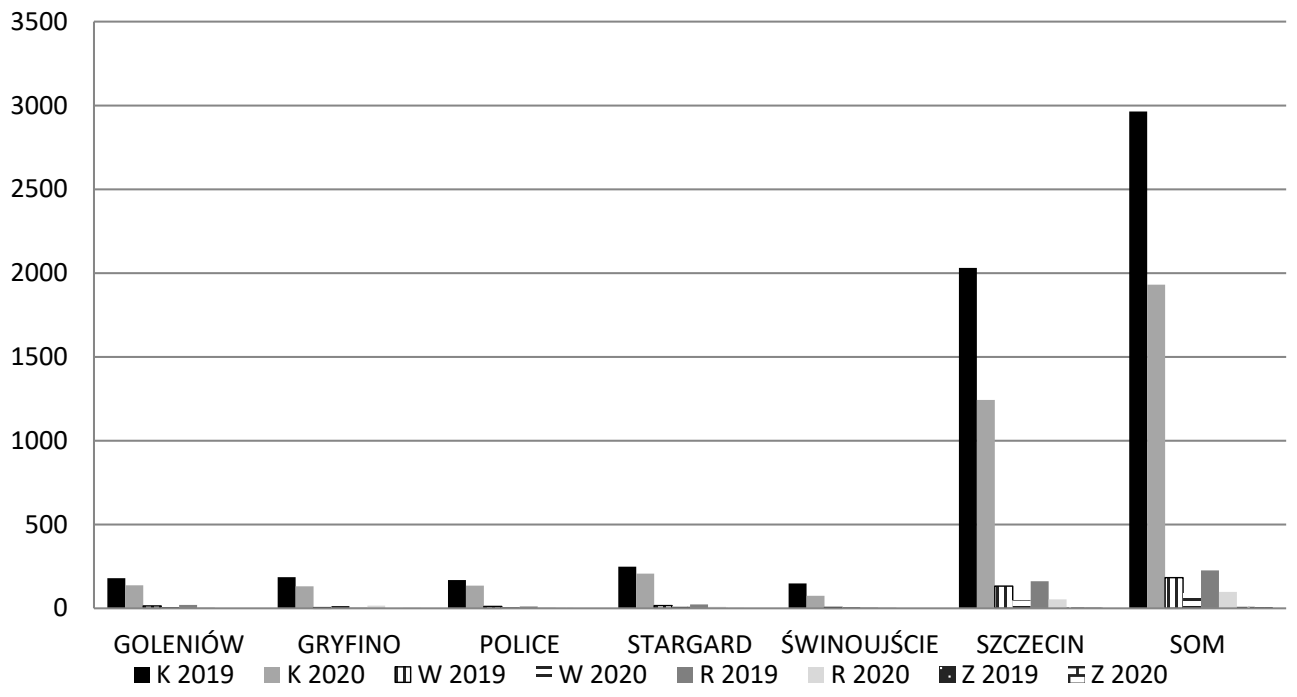

Rysunek 1. Liczba kolizji (K), wypadków (W), rannych (R) oraz zabitych (Z) na terenie SOM-u w badanym okresie

Źródło: opracowanie własne na podstawie danych uzyskanych z Komendy Wojewódzkiej Policji w Szczecinie.

Wzrost liczby osób rannych i zabitych wpłynął również na statystykę tzw. przestępstw drogowych (dane dotyczące przestępczości). Wzrost ten jest widoczny na kolejnym zestawieniu. Jednak ogólna, wyraźna tendencja spadkowa na obszarze SOM-u jest rezultatem znacznie niższej niż w roku ubiegłym liczby zdarzeń odnotowanych na terenie Szczecina. Autor podkreśla znaczący spadek liczby ofiar zdarzeń drogowych, co ma również istotne znaczenie w zakresie oczekiwań społecznych związanych z poprawą bezpieczeństwa na drogach. Uzasadnia to sformułowanie tezy, że w początkowym okresie epidemii koronawirusa SARS-CoV2 stan bezpieczeństwa nie uległ pogorszeniu, a wręcz zdecydowanie poprawił się.

Autor nadmienia również, że odnotowano także znaczne spadki w ogólnej liczbie interwencji przeprowadzonych przez policjantów na terenie SOM-u. Wynoszą one w analizowanym okresie w liczbach bezwzględnych 36596 w 2019 roku oraz $33449 \mathrm{w}$ roku 2020.

Istotnym kryterium ocennym określającym stan bezpieczeństwa jest zagrożenie przestępczością kryminalną. W tym celu autor wybrał pięć niżej wskazanych kategorii przestępstw: 
- bójka i pobicie,

- $\operatorname{kradzież~(w~tym~cudzej~rzeczy,~pojazdu~oraz~z~włamaniem),~}$

- rozbój (w tym kradzieże i wymuszenia rozbójnicze),

- przestępstwa narkotykowe (w tym posiadanie i udzielanie),

- przestępstwa drogowe.

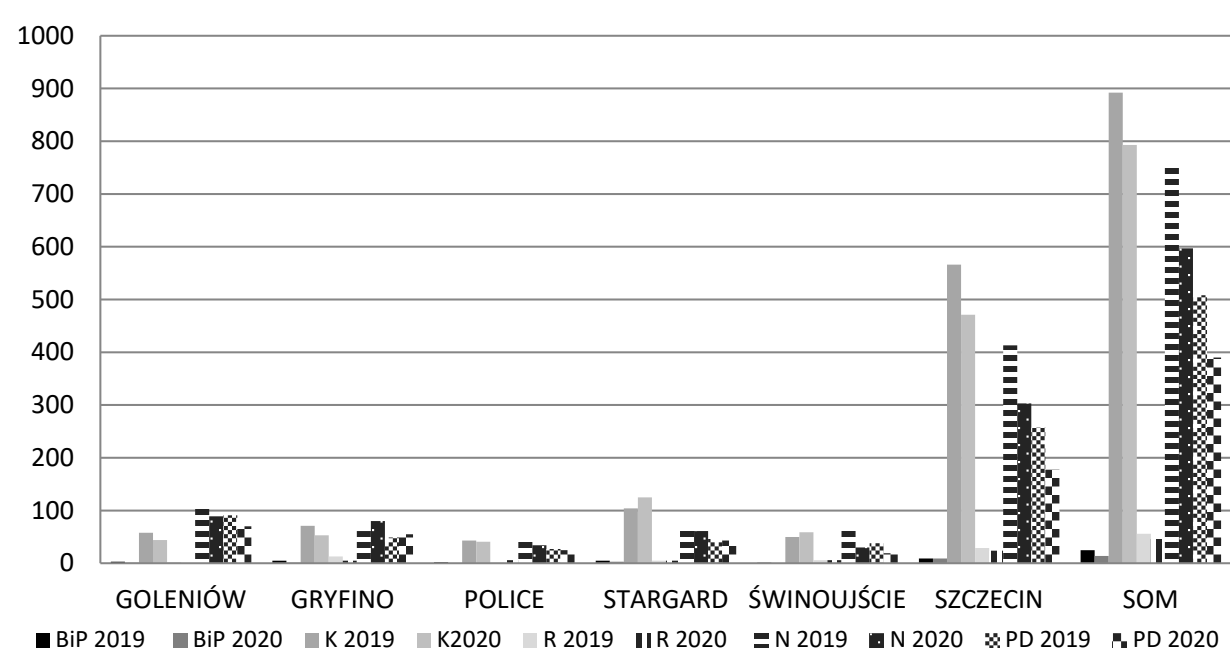

Rysunek 2. Liczba wybranych kategorii przestępstw wszczętych przez jednostki policji właściwe terytorialnie dla obszaru SOM-u (bójki i pobicia - BiP, kradzieże $-\mathrm{K}$, rozboje $-\mathrm{R}$, przestępstwa narkotykowe $-\mathrm{N}$, przestępstwa drogowe - PD)

Źródło: opracowanie własne na podstawie danych uzyskanych z Komendy Wojewódzkiej Policji w Szczecinie.

Wskazane na rysunku 2 dane obrazują liczbę postępowań wszczętych, przez które należy rozumieć ,[...] postępowanie wszczęte przez jednostkę organizacyjną Policji w związku ze zdarzeniem, co do którego zachodzi podejrzenie, że jest przestępstwem, albo wszczęte przez prokuraturę i przekazane Policji do dalszego bezpośredniego prowadzenia. Do postępowań wszczętych doliczane są również dochodzenia wszczęte faktycznie, a następnie zakończone wydaniem postanowienia o umorzeniu i wpisaniu sprawy do rejestru przestępstw"21. W ocenie autora ten rodzaj danych trafnie oddaje rzeczywistą liczbę przestępstw. Wyraźna

${ }^{21}$ Uwagi $i$ definicje, dostęp 22.06.2020, http://statystyka.policja.pl/st/przestepstwa-ogolem/ przestepstwa-kryminalne/63470, Przestepstwa-kryminalne-ogolem.html. 
tendencja spadkowa wystąpiła na terenie większości jst tworzących SOM. Należy jednak podkreślić, że odnotowano wzrost liczby przestępstw narkotykowych i drogowych (na terenie Gryfina) oraz kradzieży (na terenie Stargardu i Świnoujścia). Pomimo tego kilkunastoprocentowe spadki we wszystkich analizowanych kategoriach przestępstw wskazują, że zmalało zagrożenie najbardziej dolegliwymi przestępstwami, na co zapewne decydujący wpływ miały obowiązujące ograniczenia wynikające ze stanu epidemii.

Na podstawie przedstawionych danych autor stwierdza, że w analizowanym okresie odnotowano statystyczną poprawę stanu bezpieczeństwa publicznego pozostającego w kompetencjach zachodniopomorskiej Policji.

Kolejnym wybranym obszarem poddanym analizie był stan bezpieczeństwa pożarowego. Jego charakterystyka obejmuje trzy podstawowe kategorie zdarzeń (pożary, zagrożenia miejscowe i fałszywe alarmy). Zagrożenia miejscowe definiowane są jako ,[...] inne niż pożar zdarzeni[a] wynikające z rozwoju cywilizacyjnego, działań człowieka lub naturalnych sił przyrody, stwarzające zagrożenie dla życia, zdrowia, mienia lub środowiska”. Zostały one dodatkowo podzielone ze względu na skalę jako: małe, lokalne, średnie, duże i gigantyczne (obejmujące klęskę żywiołową). Inną typologią, którą stosuje straż pożarna, jest podział ze względu na rodzaj zagrożenia (wyspecyfikowano ich 14). Poprzez alarm fałszywy należy natomiast rozumieć ,,[...] wezwania podmiotów [...] do zdarzeń, które faktycznie nie miały miejsca", a które klasyfikuje się jako złośliwe, w dobrej wierze oraz z instalacji wykrywania ${ }^{22}$. Na rysunku 3 zestawiono dane w ujęciu trzymiesięcznym (marzec-maj) ubiegłego i bieżącego roku bez podziału na poszczególne miesiące. Jednak autor wyraża pogląd, że pozostaje to bez istotnego wpływu na wnioskowanie. Zauważalna jest wyraźna pozytywna tendencja w zakresie spadku liczby pożarów (o 15\%) i co ważne, spadek ten został odnotowany w każdej z jst. Odmiennie przedstawiają się dane w pozostałych dwóch kategoriach, gdzie odnotowano znaczne wzrosty (odpowiednio ZM-165\% i FA - 46\%), które są wyłącznie wynikiem dodatkowych zadań zleconych Państwowej Straży Pożarnej. Takie właśnie zadania i działania polegające na udzielaniu wsparcia i pomocy innym służbom kwalifikowane były również do zagrożeń miejscowych. Obejmowały one m.in. pomiar temperatury osób przebywających na statkach wpływających do portów Szczecina i Świnoujścia, rozstawianie oraz bieżące utrzymanie namiotów pneumatycznych wraz z nagrzewnicami na terenie

${ }^{22}$ Zasady ewidencjonowania, dostęp 23.06.2020, https://www.straz.gov.pl/download/583, 34-38. 
placówek medycznych, wsparcie policji oraz straży gminnych i miejskich w przekazywaniu komunikatów głosowych z pojazdów służbowych w okresie obostrzeń spowodowanych epidemią. Dlatego wzrost tych zagrożeń pozostaje bez istotnego wpływu na stan bezpieczeństwa przeciwpożarowego na terenie SOM-u. Zdecydowanie negatywnie należy postrzegać znaczny wzrost liczby fałszywych alarmów, na co wpływ ma zero-jedynkowe ich rejestrowanie w systemie wspomagania dowodzenia PSP. Przykładem takich działań jest wyjazd sekcji bojowej do zdarzenia polegającego na pomocy przy otwarciu drzwi do lokalu, które po przybyciu PSP na miejsce wezwania zostały otwarte przez właściciela lub zarządzającego. Taki alarm traktowany jest w statystyce jako fałszywy.

Autor wyraża zdecydowany pogląd, że do tej liczby mogła przyczynić się również izolacja społeczna. Uwzględniając wszystkie analizowane czynniki, autor uznał, że stan epidemii nie wpłynął negatywnie na stan bezpieczeństwa pożarowego na terenie SOM-u.

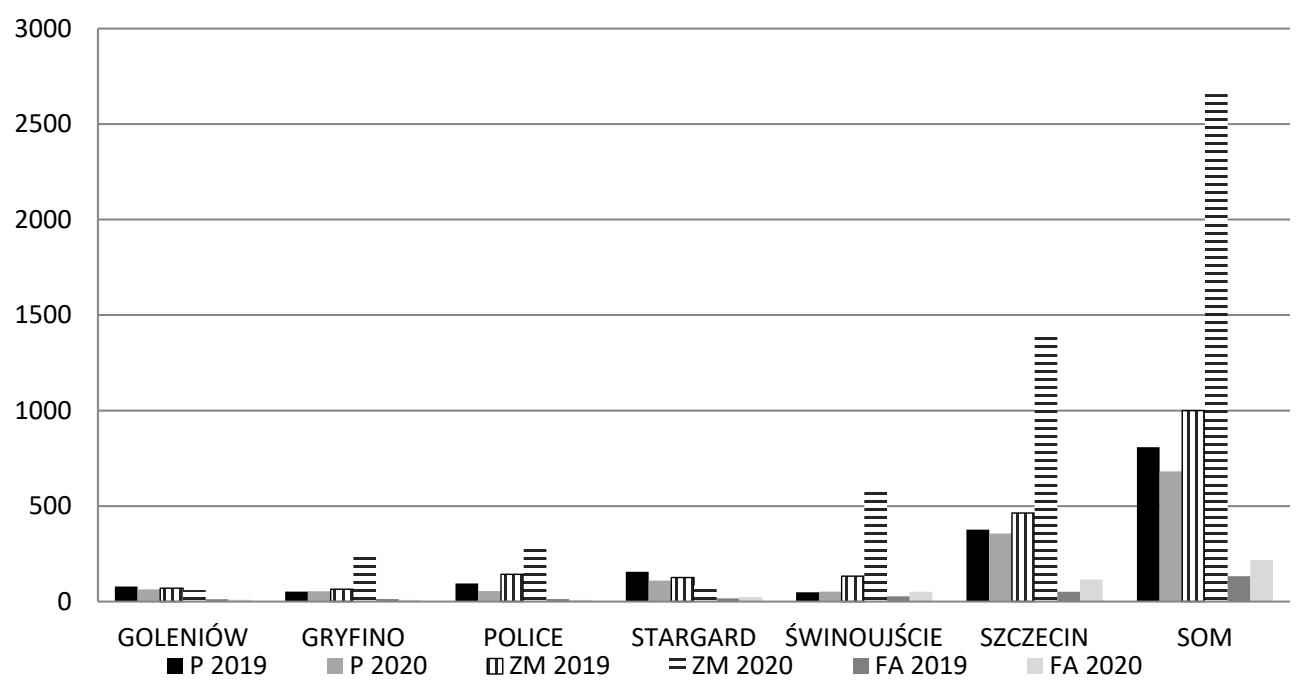

Rysunek 3. Liczba pożarów - P, zagrożeń miejscowych - ZM oraz fałszywych alarmów - FA na terenie SOM-u w analizowanym okresie

Źródło: opracowanie własne na podstawie danych uzyskanych z Komendy Miejskiej Państwowej Straży Pożarnej w Szczecinie.

Ostatnią analizowaną zmienną była liczba zachorowań, zgonów spowodowanych przez koronawirusa SARS-CoV-2 w okresie od 1 marca do 31 maja 2020 roku. Uzyskane dane przedstawione na kolejnym rysunku obrazują stan 
oraz rozwój epidemii na terenie powiatów wchodzących w skład SOM-u. Na rysunku nie ujęto liczby testów, które przeprowadzono w kolejnych miesiącach (w marcu - 1213, kwietniu - 7862 oraz w maju - 15 826). Liczba ta jest wynikiem niedostatecznego przygotowania diagnostycznego, w tym braku testów. Miało to zapewne również bezpośredni wpływ na liczbę ujawnionych zachorowań. Sama ich liczba (149) jest stosunkowo niska, biorąc pod uwagą wielkość populacji zamieszkującej obszar SOM-u. Nadto należy podkreślić, że na terenie Szczecina zlokalizowany został jeden szpital tzw. Jednoimienny, czyli w całości przeznaczony na leczenie osób zarażonych koronawirusem z obszaru całego województwa. Autor nie podejmuje się wnioskowania w tym zakresie, ponieważ szczegółowa interpretacja tych danych powinna być uzupełniona np. ustaleniem przyczyn zgonów, te zaś można określić wyłącznie badaniem patologicznym.

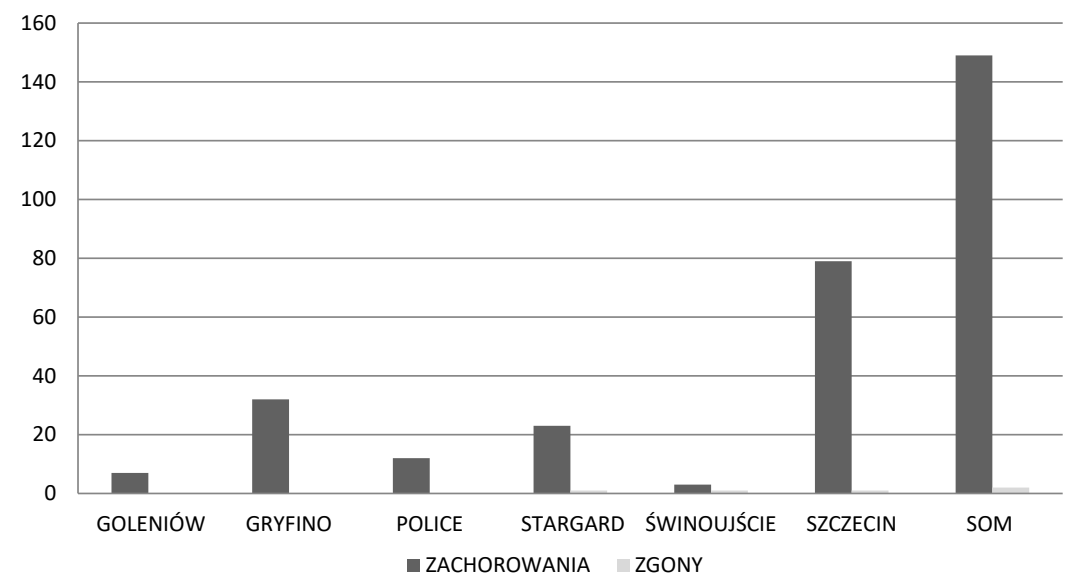

Rysunek 4. Liczba zachorowań i zgonów na COVID-19 na terenie SOM-u Źródło: opracowanie własne na podstawie danych uzyskanych od Zachodniopomorskiego Państwowego Wojewódzkiego Inspektora Sanitarnego w Szczecinie.

Odnotowane zgony w analizowanym okresie stanowią promil ich ogólnej liczby. Autor uzyskał z Urzędu Stanu Cywilnego w Szczecinie dane obejmujące wszystkie jst tworzące SOM. Wskazują one jednoznacznie, że pomimo wzrostu liczby zgonów na terenie Szczecina (ich liczba nieznacznie wzrosła z 1100 w 2019 r. do 1103 w 2020 r.), ich liczba na obszarze całego SOM-u spadła o blisko $5 \%$ (liczbowo - spadek o 85). Wszystkie pozostałe jst odnotowały ich spadek. Dane te jednoznacznie wskazują, że zachorowalność i umieralność spowodowana epidemią koronawirusa nie stanowiła istotnego zagrożenia dla mieszkańców SOM-u. 


\section{Podsumowanie}

Autor, wykorzystując metodę badań dokumentów, dokonał charakterystyki wybranych rozwiązań normatywnych oraz funkcjonalnych umożliwiających przeciwdziałanie zagrożeniu stanem epidemii. Wykorzystał również zmienne ilościowe, które dotyczyły trzech zasadniczych obszarów: ochrony zdrowia, bezpieczeństwa publicznego, w tym w ruchu drogowym, oraz ochrony przeciwpożarowej. Przyjął założenie, że na podstawie porównania danych liczbowych (zachorowania, zgony, stan przestępczości, osoby zabite czy ranne w wypadkach, bezpodstawne wezwania) zarejestrowanych w zasobach statystycznych wybranych podmiotów możliwe będzie ustalenie stanu bezpieczeństwa w badanym okresie na obszarze SOM-u. Należy przy tym zaznaczyć, że na potrzeby niniejszego opracowania autor za tożsamy uznał stan zagrożenia epidemiologicznego i stan epidemii. Przedstawione dane wskazują jednoznacznie, że odnotowane w statystykach wartości liczbowe w 2020 roku były zdecydowanie niższe niż w analogicznym okresie 2019 roku. Dotyczy to wszystkich badanych zmiennych charakteryzujących obszar SOM-u. Jednocześnie autor dostrzegł jednostkowe odstępstwa odnotowywane w niektórych z powiatów, co jednak pozostaje bez istotnego wpływu na ostateczne wnioski.

Dokonane ustalenia pozwalają na udzielenie odpowiedzi na pierwsze z pytań, tzn. czy stan epidemii w pierwszych trzech miesiącach jej trwania wpłynął na obniżenie poziomu bezpieczeństwa mieszkańców Szczecińskiego Obszaru Metropolitalnego.

Autor jednoznacznie stwierdził, że wprowadzenie stanu epidemii na obszarze Rzeczpospolitej Polskiej nie wpłynęło na obniżenie poziomu bezpieczeństwa mieszkańców Szczecińskiego Obszaru Metropolitalnego w analizowanym okresie. Przemawiają za tym wszystkie analizowane zmienne. Jednym $z$ determinantów wpływających na stan bezpieczeństwa była zmniejszona aktywność mieszkańców w przestrzeni publicznej. Do takiej konkluzji skłania przede wszystkim znaczny spadek liczby poruszających się pojazdów (dane z GMS), co skutkowało znacznym spadkiem liczby zdarzeń (z osobami zabitymi i rannymi) na terenie całego SOM-u.

Postawiona przez autora hipoteza nie uległa falsyfikacji. 


\section{Bibliografia}

Apanowicz, Jerzy. Metodologia ogólna. Gdynia: Bernardinum, 2002.

Chodubski, Andrzej Jan. Wstęp do badań politologicznych. Gdańsk: Wydawnictwo Uniwersytetu Gdańskiego, 2011.

Dane o województwie - kwiecién 2020. Dostęp 31.05.2020. https://szczecin.stat.gov.pl/ wojewodztwo/.

Jakubczak, Ryszard., red. Obrona narodowa w tworzeniu bezpieczeństwa III RP. Warszawa: Bellona, 2003.

Koncepcja Przestrzennego Zagospodarowania Kraju 2030. Dostęp 25.06.2020. http:// www.wzs.wzp.pl/sites/default/files/files/19683/89272000_1412985316_Koncepcja_ Przestrzennego_Zagospodarowania_Kraju_2030.pdf.

Miejski Plan. Dostęp 14.06.2020. http://bip.um.szczecin.pl/files/5F5F2355610B4CF0935EDF038D14EBB0/Miejski_Plan_Zara\%C4\%85dzania_Kryzysowego.pdf.

Prezydent Szczecina i mieszkańcy apeluja. Otwórzcie przejście graniczne w Lubieszynie! Twojeradio.fm. Dostęp 21.06.2020. https://twojeradio.fm/prezydent-szczecina-i-mieszkancy-apeluja-otworzcie-przejscie-graniczne-w-lubieszynie.html.

Rozporządzenie Ministra Edukacji Narodowej z 11.03.2020 w sprawie czasowego ograniczenia funkcjonowania jednostek sytemu oświaty w związku z zapobieganiem, przeciwdziałaniem i zwalczaniem COVID-19. Dz.U. 2020, poz. 410.

Rozporządzenie Ministra Zdrowia z 13.03.2020 w sprawie ogłoszenia na obszarze Rzeczypospolitej Polskiej stanu zagrożenia epidemicznego. Dz.U. 2020, poz. 433.

Rozporządzenie Ministra Zdrowia z 20.03.2020 w sprawie ogłoszenia na obszarze Rzeczypospolitej Polskiej stanu epidemii. Dz.U. 2020, poz. 491.

Rozporządzenie Rady Ministrów z 31.03.2020 w sprawie ustanowienia określonych ograniczeń, nakazów i zakazów w związku z wystąpieniem stanu epidemii. Dz.U. 2020, poz.566, z późn. zm.

Rozporządzenie Rady Ministrów z 10.04.2020 w sprawie ustanowienia określonych ograniczeń, nakazów i zakazów w związku z wystąpieniem stanu epidemii. Dz.U. 2020, poz. 658 .

Rozporządzenie Rady Ministrów z 29.05.2020 w sprawie ustanowienia określonych ograniczeń, nakazów i zakazów w związku z wystąpieniem stanu epidemii. Dz.U. 2020, poz. 964.

Ustawa z 26.04.2007 o zarządzaniu kryzysowym. Dz.U. 2007, nr 89, poz. 590, z późn. zm.

Ustawa z 5.12.2008 o zapobieganiu oraz zwalczaniu zakażeń i chorób zakaźnych u ludzi. Dz.U. 2008, nr 243, poz. 1570, z późn. zm.

Ustawa z 2.03.2020 o szczególnych rozwiązaniach związanych z zapobieganiem, przeciwdziałaniem i zwalczaniem COVID-19, innych chorób zakaźnych oraz wywołanych nimi sytuacji kryzysowych. Dz. U. 2020, poz. 374. 
Uwagi $i$ definicje. Dostęp 22.06.2020. http://statystyka.policja.pl/st/przestepstwa-ogolem/przestepstwa-kryminalne/63470,Przestepstwa-kryminalne-ogolem.html.

Współczesne kryzysy gospodarcze z perspektywy branży morskiej. Dostęp 4.07.2020. https://www.gov.pl/web/gospodarkamorska/wspolczesne-kryzysy-gospodarcze-z-perspektywy-branzy-morskiej.

Zapis przebiegu. Dostęp 16.06.2020. http://www.sejm.gov.pl/Sejm9.nsf/biuletyn.xsp? skrnr=ZDR-13.

Zasady ewidencjonowania. Dostęp 23.06.2020. https://www.straz.gov.pl/download/583.

\begin{abstract}
Abstrakt
Artykuł jest próbą określenia stanu bezpieczeństwa Szczecińskiego Obszaru Metropolitalnego (jedynego na terenie RP leżącego bezpośrednio w pasie granicy państwowej) w okresie epidemii koronawirusa SARS-CoV-2. Autor, kierując się interdyscyplinarnym podejściem badawczym, poddał analizie wiele zróżnicowanych obszarów wpływających lub charakteryzujących szeroko postrzegane bezpieczeństwo zarówno o wymiarze jakościowym (rozwiązania normatywne i planistyczne), jak i ilościowym (m.in. liczby pojazdów poruszających się po drogach publicznych, zdarzeń drogowych, wybranych kategorii przestępstw, zachorowań, zgonów oraz testów na koronawirusa, pożarów, zagrożeń miejscowych i fałszywych alarmów), które uzyskał w ramach dostępu do informacji publicznej. Na podstawie zarysowanych tendencji (w porównywalnych trzymiesięcznych okresach lat 2019 i 2020) autor ustalił odpowiedzi na dwa pytania:

- Czy stan epidemii w pierwszych trzech miesiącach jej trwania wpłynął na obniżenie poziomu bezpieczeństwa mieszkańców Szczecińskiego Obszaru Metropolitalnego?

- Czy jednym z czynników wpływających na stan bezpieczeństwa może być zmniejszona aktywność mieszkańców w przestrzeni publicznej?
\end{abstract}




\title{
THE INFLUENCE OF SARS-COV-2 EPIDEMIC ON THE SECURITY of SzCzecin Metropolitan Area
}

\begin{abstract}
In this article an attempt was made to determine the security level of Szczecin Metropolitan Area (the only one in the Republic of Poland situated within the state frontier zone) at the time of the SARS-CoV-2 epidemic. The author has adopted an interdisciplinary research approach and analyzed a number of diversified areas influencing or characterizing a broadly understood security both in the qualitative aspect (normative and planning solutions) and quantitative one (including the number of vehicles used on public roads, road events, selected categories of crimes, morbidity rate, death rate, coronavirus tests, fires, local threats, and false alarms) recognized through access to public information. Based on the outlined tendencies (within the comparable three-month periods of 2019 and 2020) the author formulated answers to two questions:

- Did the epidemic state during its first three months decreased the security level of Szczecin Metropolitan Area?

- Can limited activity of the inhabitants in the public sphere be one of the security level determinants?
\end{abstract}

